\title{
Nuorten kokonaisrikollisuuden seuranta ja rikosten ehkäisy oikeusministeriössä
}

\author{
AARNE KINNUNEN
}

Nuoret ovat erityisasemassa rikosoikeudellisessa ja kriminaalipoliittisessa keskustelussa ja päätöksenteossa. Nuorten tekemä rikollisuus ja nuorten uhrikokemukset ovat myös median kestoaihe. Nuoruusikään kuuluu oman identiteetin etsiminen ja rajojen kokeilu, osalla myös lainvastaisten tekojen tekeminen. Nuoruusikä onkin elämänkaaressa rikosaktiivista aikaa (Honkatukia \& Kivivuori 2006). Tavallisesti rikollisuus on ohimenevä vaihe ja rikokset vähäisiä. Toistuva ja vakava rikollisuus sen sijaan kasautuu pienelle joukolle nuoria. Nopeaa puuttumista nuorten tekoihin pidetään tärkeänä, mutta samalla halutaan välttää nuorten rikollisiksi leimaamista. Nuoriin kohdistuvia seuraamuksia ja rikollisuutta ehkäiseviä toimia tuleekin suunnitella harkitusti. Tästä syystä nuorten rikollisuutta kuvaavat tietokannat, indikaattorit ja tutkimukset ovat erityisen tärkeitä. $\mathrm{Ne}$ antavat selkärankaa ja suuntaa suunniteltaville politiikkatoimille.

Tässä puheenvuorossa tarkastelen sitä, miltä nuorten rikollisuus tutkimusten ja seurantaindikaattoreiden valossa näyttää, minkälaista tutkimus- ja seurantatietoa on käytettävissä, miten ja minkä tyyppistä käyttöä varten nuorten kokonaisrikollisuuden seurantaa tehdään sekä miten tutkimukseen perustuvan suunnittelun ja päätöksenteon tärkeys korostuu nykypäivän hallinnollisessa ajattelussa.

\section{Tieto rikollisuuden taustatekijöistä tärkeää politiikkatoimia suunniteltaessa}

Nuorten rikollisuudesta ja uhrikokemuksista saatava tutkimustieto on erittäin tärkeää poli- tiikkatoimia suunniteltaessa. Tietoja nuorisorikollisuuden kehityksestä käytetään lainsäädäntöhankkeiden vaikuttavuusarvioinneissa sekä ennen lainsäädäntöuudistusta että sen jälkeen. Myös nuorisorikollisuuden ehkäisytyössä on olennaista, että on käytettävissä ajantasaista tietoa rikollisuuden kehityksestä ja piirteistä. Näin pystytään suunnittelemaan rikoksentorjuntatoimia ja esimerkiksi kohdentamaan rahoitushakuja akuutteihin rikollisuusongelmiin. Rikollisuuden seurantatietoja käytetään myös vuosittaisissa valtioneuvoston tuloksellisuuden raportoinneissa.

Politiikkasuunnittelussa keskeisiä tiedonintressejä ovat nuorisorikollisuuden määrä ja laatu. Vastoin yleistä käsitystä tutkimukset osoittavat, että nuorten rikollisuus on vähentynyt 2000-luvun alun jälkeen. Toisaalta tuoreen vuonna 2021 julkaistun tutkimuksen mukaan nuorten rikoskäyttäytymisen ja uhrikokemusten vähentymistrendi näyttää pääosin päättyneen. Valtaosa tutkituista teoista ja uhrikokemuksista oli pysynyt samalla tasolla kuin vuonna 2016, vaikka myös joitain muutoksia oli nähtävissä. (Kaakinen \& Näsi, 2021.) Poliisitilastojen mukaan nuorten yleisin rikos on näpistys. Kyselytutkimusten mukaan nuorten yleisimpiä kiellettyjä tai rikollisia tekoja ovat alkoholin humalajuominen, luvattomat poissaolot koulusta, luvaton verkkolataaminen ja koulusta varastaminen. Viime vuosina alaikäisten juominen on vähentynyt samalla kuin huumeiden käyttö on lisääntynyt. (Danielsson, 2020.) Siltikin rikoksia tekevien nuorten elämänkulkuun liittyvät usein päihteet. 
Vaikka yhä harvemmat nuoret syyllistyvät rikoksiin ja erityisesti vakaviin rikoksiin, toistuva rikollisuus kasautuu pienelle joukolle. Toistuva rikoskäyttäytyminen on yhteydessä laaja-alaisiin ongelmiin monilla elämän osaalueilla, kuten ristiriitoihin perheessä, koulun keskeyttämiseen, päihteiden käyttöön ja elämänhallinnan heikkenemiseen. Tämä pieni joukko putoaa usein palveluiden piiristä. Tästä seuraa nuorten polarisoitumista, joka syventää eriarvoisuutta nuorisoikäisten välillä, sillä rikoksia tekevät nuoret ovat marginaalisessa asemassa paitsi yhteiskunnassa yleensä myös ikätovereittensa joukossa. (Haikkola ym., 2019.)

Politiikkatoimia suunniteltaessa on pidettävä mielessä, että nuoret ovat rikoksentekijöinä muita ikäryhmiä aktiivisempia, mutta myös uhrikokemukset kasautuvat nuoriin. Yleisimpiä uhrikokemuksia nuorille olivat kyselyjen mukaan heidän omaisuuteensa kohdistuneet vahingonteot, kiusaaminen somessa, varkaudet ja väkivallalla uhkailu. Nuoret kokevat fyysistä väkivaltaa useimmiten toisen nuoren tekemänä. Väkivallan tekijä on yleensä nuorelle tuttu ennestään. Seksuaalista häirintää nuoret kokevat sekä toisten nuorten että aikuisten taholta. Viime vuosikymmeninä lasten ja nuorten kokema seksuaalinen väkivalta ja nuorten seksuaalinen kanssakäyminen aikuisten kanssa on onneksi vähentynyt. (Niemi, 2018.)

Lapsiuhritutkimusten mukaan lapsiin kohdistuva kuritusväkivalta on vähentynyt viime vuosikymmeninä ja asenteet sitä kohtaan ovat muuttuneet kielteisemmiksi. Siltikin lapsiin kohdistuvaa väkivaltaa pidetään yleisesti edelleen hyväksyttävämpänä kuin aikuisiin kohdistuvaa väkivaltaa. Yleisin vanhempien lapsiinsa käyttämä fyysinen kuritusmuoto on tukistaminen. (Fagerlund ym., 2014.)

Lastensuojelun toimenpiteenä kodin ulkopuolelle sijoitetut tai sijaishuollossa olleet nuoret ovat muita ryhmiä taipuvaisempia rikollisuuteen niin nuoruudessa kuin aikuisiällä (Ristikari ym., 2018). Rikoksiin toistuvasti syyllistyviä laitosnuoria uhkaa moninkertainen syrjäytyminen ja pysyvä leimautuminen, jonka seuraukset voivat jatkua läpi elämän.

Nuorten rikollisuus aiheuttaa välittömiä taloudellisia kustannuksia ja inhimillistä kärsimystä, mutta se on myös yhteydessä aikuisuuden rikosuraan: valtaosa aikuisista taparikollisista on jo nuorena oireillut rikoskäyttäytymisellä (Honkatukia \& Kivivuori, 2006). Kun ehkäistään nuorisorikollisuutta tai puututaan siihen, onkin ensiarvoisen tärkeää kohdistaa toimenpiteitä siihen joukkoon nuoria, jolle vakavat rikokset kasautuvat. Heidän riskinsä ajautua rikolliseen elämäntapaan on suurempi kuin muiden. Riskiryhmään kuuluvien nuorten löytäminen edellyttää viranomaisten välistä yhteistyötä ja tiedonkulkua lainsäädännön asettamissa rajoissa.

Riskinuorten tunnistaminen ja ohjaaminen pois rikoksista estää ennalta rikoskierteiden muodostumista ja rikosten uhriksi joutumista sekä aiheuttaa yhteiskunnalle merkittäviä säästöjä. Politiikkatoimien tavoitteista ollaan kutakuinkin yksimielisiä, mutta toimien suunnitteluun ja toteuttamiseen tarvitaan tietoa, tutkimusta ja poliittista tahtoa.

\section{Tutkimukseen perustuva päätöksenteko}

Yhteiskunnalliseen päätöksentekoon kohdistuu monia eri suuntaan risteäviä muutospaineita. Internetin ja sosiaalisen median aikakaudella päätöksenteon pitäisi pystyä reagoimaan kansalaisten tarpeisiin entistä nopeammin sekä olla osallistavampaa, avoimempaa ja läpinäkyvämpää. Samaan aikaan päätöksenteon pitäisi pystyä tarttumaan aikamme suuriin haasteisiin olemalla entistä pitkäjänteisempää, strategisempaa, ilmiölähtöisempää ja tietoperusteisempaa. (SITRA, 2019). 
Tiedon käyttö yhteiskunnallisessa päätöksenteossa onkin yhä keskeisempi valtionhallinnon kehittämiskohde. Nykyisin katsotaan, että päätöksenteossa on pystyttävä kokoamaan monimuotoista tietoa ja asiantuntemusta yhteen, lisäämään kansalaisten osallisuutta sekä hyödyntämään uusia digitaalisen tiedonkäytön mahdollisuuksia. Päätöksenteon valmistelusta vastaavien on tunnettava erilaiset tiedonkäytön lähestymistavat sekä osattava suunnitella tiedonkäyttö kuhunkin tilanteeseen parhaiten soveltuvalla tavalla. (SITRA, 2019).

Kriminaalipoliittisessa päätöksenteossa tutkimuksella onkin erittäin tärkeä rooli. Rikollisuusongelmiin kytkeytyvää epävarmuutta ja turvattomuutta saatetaan käyttää välineenä poliittisten tavoitteiden saavuttamiseen. Rangaistukset ja rikoslaki ovat kriisien uhatessa tarjonneet poliittisesti houkuttelevan keinon turvallisuusuhkien torjumiseksi. Nykyisin rikollisuusongelmat saatetaan kytkeä esimerkiksi maahanmuuttokeskusteluun päämäärähakuisesti. Rikollisuusongelmiin vastauksia etsittäessä nousevat helposti tunteet pintaan. Moraalinen närkästys johtaa usein rankaisullisen keinovalikoiman korostamiseen. Median rooli on noussut yhä keskeisemmäksi. Internetin keskustelupalstat luovat omaa todellisuuttaan, joka ei välttämättä ole faktaperustaista. Näin tutkimukseen perustuvan tiedon rooli nousee yhä tärkeämpään asemaan. Tutkimuksen ja tiedon levittämisen avulla pyritään tuomaan objektiivista aineistoa poliittiseen päätöksentekoon. Luonnollisesti arvovalinnat tästä huolimatta aina jossain määrin ohjaavat päätöksentekoa. Tärkeää kuitenkin on, että poliittisten päätösten yhteiskunnallisia vaikutuksia pystytään mahdollisimman hyvin etukäteen arvioimaan ja jälkikäteen seuraamaan.

Oikeusministeriössä lähtökohtana on, että tutkimustoiminta ja tietovarantojen hyödyntäminen tukevat ministeriön strategian ja tu- lostavoitteiden toteuttamista. Tämän toteutumiseksi valmistelun ja konkreettisen päätöksenteon tueksi tulee olla saatavilla laadukas tietopohja. Tietopohjan tulee myös olla helposti käytettävää. Tietopohjan hyödyntäminen puolestaan edellyttää, että virkakunnalla on riittävät valmiudet tiedon hankintaan ja tietolähteiden monipuoliseen käyttöön. Oikeusministeriön omien tietovarantojen käyttövalmiuden tulisi tulevaisuudessa olla keskeinen osa henkilöstön ammattitaitoa ja luonteva osa valmistelutyötä. Tiedolla johtamisen strategiaan kuuluu data-analytiikan lisäksi valmiudet tietopohjan visualisointeihin ja raportointiin. Tietovarantojen käytettävyyttä ja tutkimustoiminnan prosesseja tulee kehittää systemaattisesti yhteistyössä muiden valtioneuvoston toimijoiden kanssa.

Tutkimustieto ja tiedon hyödyntämistaito tukevat toimintaympäristön ilmiöiden ja muutosten ymmärtämistä sekä ennakointia. Lisäksi on tärkeää seurata politiikkatoimien vaikuttavuutta hyödyntämällä tähän kehitettyjä tutkimusmenetelmiä. Keskeistä on seurata lainsäädäntöhankkeiden vaikuttavuutta sekä ex-ante että ex-post menetelmien avulla. Lainsäädäntötutkimusten lisäksi tärkeää on vahvistaa oikeusministeriön muun kehittämistyön seurantaa ja tutkimusta. Erityisesti rikoksentorjuntamenetelmien vaikuttavuustutkimus on alue, joka vaatii vahvistamista tulevaisuudessa.

Tutkimustiedon saatavuutta ja hyödynnettävyyttä on tehostettava valmistelussa ja päätöksenteossa. Valmistelijoiden tutkimusosaamista on jatkuvasti vahvistettava ja tarjottava tähän koulutusta. Kehittämistyön tulee tapahtua niin ministeriössä kuin valtioneuvostotasolla yleisemminkin. Tutkimusrahoitusta ja tutkimuksen tilaajaosaamista tulee vahvistaa.

Tietoon ja tutkimukseen perustuvaa päätöksentekoa tulee kehittää yhteistyössä yliopistojen kanssa Suomessa ja kansainvälisesti. Tietoon perustuva päätöksenteko edellyttää 
hyvää tietopohjaa, analyysitaitoja ja poliittista tukea onnistuakseen. On kuitenkin todettava, että tutkimukseen perustuvan päätöksenteon paradigma ei välttämättä ole aivan niin yksinkertaista kuin edellä kuvataan. Yhteiskuntatieteelliset kysymykset eivät välttämättä taivu kokeellisiksi tutkimusasetelmiksi, vaan lisäksi tarvitaan muun tyyppistä päättelyä politiikkatoimien tueksi. Kokeellisen tutkimusasetelman rakentaminen voi olla vaikeaa esimerkiksi eettisten kysymysten vuoksi tai se voi olla yksinkertaisesti liian kallista. Tutkimukseen perustuvan päätöksenteon paradigman ei tulisi tarpeettomasti rajoittaa politiikkatoimien käyttöalaa.

Lisäksi yhteiskunnallisten interventioiden vaikuttavuusarvioinneilla on todettu olevan useita ulottuvuuksia. Ei riitä, että etsimme vastausta kysymykseen, onko tämä menetelmä toimiva. Sen sijaan meidän tulee kysyä "mikä toimii ja kenelle, minkälaisessa ympäristössä ja minkälaisten reunaehtojen vallitessa, ja miten?" (Pawson \& Tilley, 1997.)

\section{Miten nuorten rikollisuutta ja uhrikokemuksia tutkitaan ja seurataan?}

Tietoa nuorten rikollisuustilanteesta tarvitaan oikeusministeriön hallinnonalalla ja rikoksentorjunnassa jatkuvasti strategisessa suunnittelussa ja toimintaohjelmissa. Tietoa tarvitaan sekä yleisen rikollisuustilanteen seurannassa että toteutettujen toimenpiteiden vaikuttavuuden arvioinnissa. Oikeusministeriön näkökulmasta nuorten kokonaisrikollisuuden indikaattorit ovat tässä työssä keskeisiä. Tärkeää on, että kaikilla yhteiskunnan sisäisestä turvallisuudesta vastaavilla hallinnonaloilla oikeusministeriön lisäksi etenkin sisäministeriöllä, sosiaali- ja terveysministeriöllä sekä opetus- ja kulttuuriministeriöllä - on yhtenäinen kuva nuorten rikollisuus- ja turvallisuustilanteesta.

Nuoria rikoksen tekijöinä ja uhreina tarkastellaan pääsääntöisesti kolmen tietolähteen avulla. Tietolähteet ovat poliisin tietoon tullut tilastoitu rikollisuus, uhritutkimukset ja itse ilmoitetun rikollisuuden kyselyt. Poliisin tilastoja tarkasteltaessa on otettava huomioon, että tilastoihin vaikuttavat nuorten rikoskäyttäytymisen ohella lukuisat muut tekijät kuin varsinaiset muutokset nuorten rikoskäyttäytymisessä. Muun muassa väestön ilmoittamisalttiudessa sekä viranomaiskontrollin tehossa ja kohdistumisessa tapahtuvat muutokset vaikuttavat tilastoituun rikollisuuteen. Myös lainsäädännön muutoksilla on oma vaikutuksensa. Syylliseksi epäiltyjen määrää koskevat tiedot perustuvat poliisin selvittämien rikosten määrään, joten myös rikosten selvitysasteen muutokset voivat vaikuttaa niihin. Poliisin tilastot perustuvat pääsääntöisesti niin kutsuttuihin bruttotilastoihin eli sama henkilö voi olla vuoden aikana syylliseksi epäiltynä useista rikoksista ja sisältyä siten tilastoon useita kertoja.

Kriminologian ja oikeuspolitiikan instituutissa (KRIMO) on tehty väestötason uhritutkimuksia vuodesta 1980 lähtien, jolloin toteutettiin ensimmäinen Kansallinen uhritutkimus. Vuonna 2012 instituutissa aloitettiin uusi Kansallinen rikosuhritutkimus (ent. Kansallinen turvallisuuskysely), joka on ensisijaisesti rikollisuutta ja rikollisuuden pelkoa mittaavaa osoitinjärjestelmä. Kansallisesti edustava kysely on kohdistettu 15-74vuotiaille Suomessa tai Ahvenanmaalla vakituisesti asuville henkilöille. Järjestelmä jatkaa vuosina 1980-2009 toteutettujen Kansallisten uhritutkimusten edustamaa tutkimuslinjaa. Kansallinen rikosuhritutkimus on nyt toteutettu vuosittain 2012-2020. Vuodesta 2008 lähtien lapsille on toteutettu oma rikosuhritutkimuksensa. Viimeisen lapsiuhritutkimus toteutettiin 2013 Poliisiammattikorkeakoulun ja Nuorisotutkimusseuran yhteistyönä (Fagerlund ym., 2014).

KRIMO julkaisee säännöllisesti itseilmoitettuun rikollisuuteen perustuvan nuorisorikollisuuskyselyn tuloksia. Kyselyssä kysytään 
suomalaisten yhdeksäsluokkalaisten eli 15-16-vuotiaiden nuorten rikoskäyttäytymisestä ja uhrikokemuksista. Vuonna 2020 kyselyyn vastasi hieman yli 5600 nuorta. (Kaakinen \& Näsi, 2021.) Itseilmoitetun rikollisuuden mittaaminen on erityisen tärkeä apuväline kansainvälisissä vertailuissa, sillä poliisitilastot ovat erittäin heikosti vertailukelpoisia maitten välillä. Muun muassa rikosmääritelmät, rikosten ilmitulotodennäköisyys ja niiden kirjaamismenetelmät vaihtelevat niin paljon, että lukujen vertailtavuus maasta toiseen on huono. Henkirikokset ovat tästä poikkeus. Niissä vertailtavuus on kohtuullisen hyvä.

KRIMOn toteuttama oppilaitosten turvallisuustutkimus pyrkii mittaamaan harvinaisempia ja vakavampia tekomuotoja kuin otospohjaisessa koululaiskyselyssä on mahdollista tehdä. Lisäksi tutkimus kattaa oppilaitokseen instituutiona kohdistuvat rikokset (esim. vahingonteot, omaisuusrikokset). Kyseessä on oppilaitosten rehtoreille suunnattu kysely, jolla mitataan oppilaisiin, henkilökuntaan ja instituutioon kohdistunutta rikollisuutta. Tutkimuksessa otetaan huomioon myös riskitekijöitä sekä oppilaitosten turvallisuus- ja kontrollimenettelyjä. (Näsi ym., 2017.)

Terveyden- ja hyvinvointilaitoksen (THL) toteuttama kouluterveyskysely tuottaa monipuolista ja luotettavaa, maakunnallista ja paikallista seurantatietoa eri ikäisten lasten ja nuorten hyvinvoinnista, terveydestä, koulunkäynnistä ja opiskelusta, osallisuudesta sekä avun saamisesta ja palvelujen tarpeisiin vastaavuudesta. Tutkimuksessa koululaisille esitetään kysymyksiä myös kiusaamisesta, seksuaalisesta häirinnästä ja väkivallasta. Tutkimus toteutetaan joka toinen vuosi. (Lasten ja nuorten hyvinvointi, 2019.)

Vuosittain julkaistava Nuorisobarometri mittaa suomalaisten 15-29-vuotiaiden nuorten arvoja ja asenteita. Nuorisobarometri tarttuu nuorten kannalta ajankohtaisiin aiheisiin, mutta toistaa joitain tutkimuskysymyksiä säännöllisesti. Siksi se mahdollistaa myös pidemmän aikavälin asennemuutosten tarkastelun. (Myllyniemi \& Berg, 2020.) Yhteiskunnallisen suunnittelun ja poliittisen päätöksenteon tueksi tulisi ylipäätään kerätä nuorten omia kokemuksia ja näkemyksiä rikollisuuteen vaikuttavista tekijöistä. Nuorilta itseltään kerättyä tietoa tulisi nykyistä enemmän hyödyntää nuoria koskevassa päätöksenteossa. Nuorten luottamus yhteiskunnan kykyyn hoitaa rikollisuusongelmia on hyvällä tasolla. Vuoden 2018 nuorisobarometrin mukaan nuorten luottamus poliisiin ja muihin yhteiskunnallisiin instituutioihin on korkealla ja kasvanut viime vuosina.

Nuorten rikosalttiutta ja hyvinvointia tarkastellaan myös välillisin keinoin. Poliisin kotihälytysten määrä kertoo perheiden hyvinvoinnin tilanteesta. Kaupunkien ja kuntien sosiaaliviranomaisten lastensuojelutoimien määrä kuvaa lasten ja nuorten huonovointisuutta. Nuorten päihdeongelmat ovat syrjäytymisen keskeinen tuottaja ja ainesosa. Myös rikollisuus on vahvasti kytkeytynyt päihdeongelmiin. Nuorten alkoholin ja huumeiden käyttöä kuvaavat tiedot ovatkin merkittäviä nuorten hyvinvoinnin kuvaajia. Lisäksi nuorten liikennekuolemat ja vakavat liikenneonnettomuudet kertovat äärimmäisten riskien ottamisesta ja päihteiden käytöstä liikenteessä. Kasvanut lasten ja nuorten psykiatristen palvelujen kysyntä kertoo huonovointisuudesta (Haapasalo-Peso ym., 2020). Tiedetään myös, että sosiaalinen huonovointisuus periytyy (Vauhkonen ym., 2017). Syrjäytyneiden vanhempien perheissä lasten riski moniongelmaisuuteen on suuri. Tästä syystä on tarpeen seurata myös laajemmin lapsiperheiden hyvinvointia. 


\section{Rikosoikeudelliset ja rikollisuutta ehkäisevät keinot}

Nuoret ovat erityisasemassa rikosoikeusjärjestelmässä ja rangaistusten toimeenpanossa. Rankaisullisten keinojen sijaan nuorille pyritään kehittämään yhteiskuntaan integroivia puuttumiskeinoja. Laaja yhteisymmärrys vallitsee siitä, että rikosoikeudellisten toimenpiteiden sijaan ennaltaehkäisevät, erityisesti sosiaalipoliittiset ja koulutuspoliittiset toimenpiteet sekä terveydenhuolto, ovat keskeisessä asemassa pyrittäessä vaikuttamaan nuorten rikoksiin. Nuorten tekemien rikosten rankaisemisessa otetaan huomioon heidän kypsymättömyytensä ja pyritään vähentämään rankaisemisen haittavaikutuksia. Yhä vahvistuva seuraamusjärjestelmän kehityslinja on yhteiskunnan yleisten tukipalvelujen aiempaa tiiviimpi kiinnittäminen rikosoikeusjärjestelmään. Tämä koskee myös nuoria rikosoikeusjärjestelmässä. Vaikka nuorelle tuomittaisiin vankeutta tai jokin muu seuraamus, on rangaistuksen aikana tarkoitus vahvistaa niitä keinoja, joilla nuori pysyy irti rikoksista ja integroituu yhteiskuntaan. Myös rikosten sovittelu on keskeinen keino käsitellä lasten ja nuorten tekemiä rikoksia.

Nuorten rikollisuuteen puuttumisessa ehkäisevät keinot nousevat merkittävään asemaan. Vaikka varhainen puuttuminen kuuluu selvästi sosiaali- ja terveystoimelle ja opetustoimelle, nämä keinot ovat keskeisesti esillä myös oikeusministeriössä. Rikollisen elämäntavan ehkäisy olisi aloitettava varhain, mieluiten jo nuoruusiässä. Rikoksentorjunnalla on myös selvä kytkentä mielenterveystyöhön. Nuorille varhain suunnatuilla tukitoimilla on selkeä positiivinen vaikutus tulevaa rikollisuutta ehkäisevästi. Varhaisella puuttumisella tarkoitetaan tässä yhteydessä lapsille ja lapsiperheille suunnattuja palveluja, joissa voidaan tunnistaa ja ehkäistä erilaisia riskejä tai ongelmia. Tavoitteena on vaikuttaa ajoissa lapsen tai nuoren kasvuympäristöön ja ehkäistä ongelmia, jotka voivat johtaa rikosten tekemiseen myöhemmin. Onnistuneella puuttumisella tarpeeksi varhaisessa vaiheessa on myönteisiä vaikutuksia sekä sosiaalisesti että taloudellisesti.

Miten oikeusministeriön hallinnonala sitten voi torjua nuorten ajautumista rikosuralle? Tässä keskeinen rooli on rikoksentorjuntatyössä, joka valtioneuvoston työnjaossa on oikeusministeriön vastuulla. Oikeusministeriöllä ei ole rikoksentorjunnan kenttäorganisaatiota, minkä vuoksi käytännön toimijat löytyvät muualta. Oikeusministeriö tukee paikallista rikoksentorjuntatyötä, pitää yllä parasta kansallista asiantuntemusta rikoksentorjunnassa ja pyrkii olemaan perillä myös kansainvälisestä, uusia ja hyviksi havaittuja rikoksentorjuntamenetelmiä koskevasta tiedosta.

Nuorten rikollisuudesta saatavaa tutkimustietoa käytetään jatkuvasti hyväksi rikollisuutta ehkäiseviä toimia suunniteltaessa. Esimerkiksi pääministeri Marinin hallitusohjelmassa kiinnitettiin erityistä huomiota rikollisuuden ehkäisyyn ja siihen osoitettiin suhteellisen runsaasti määrärahoja hallituskauden ajaksi. Hallitusohjelmaan liittyen oikeusministeriö käynnisti rikollisuuden ehkäisyhankkeen, jossa pitkittyneet rikos- ja väkivaltakierteet pyritään ehkäisemään kokonaisvaltaiseen ja moniammatilliseen tukeen perustuvilla uusilla toimintamalleilla. Tutkimukseen perustuvien toimintamallien pilotointi on käynnistynyt valtionavustusrahoituksella neljällä paikkakunnalla (Oulussa, Rovaniemellä, Vantaalla ja Turussa). Toimintamallissa yksi vastuutyöntekijä tekee systemaattisen arvion lapsen ja nuoren sekä koko perheen tilanteesta oikean tuen kartoittamiseksi. Arvion perusteella nuorelle voidaan räätälöidä hänen tarvitsemansa tuki ja palvelut. Toimintamallissa nuoren on mahdollista osallistua ohjelmiin päihteistä ja rikoksista irtautumiseksi. Toistuvasti ja vakavia rikoksia tekevien nuorten auttamisessa on 
erityisen tärkeää panostaa siihen, että nuoren kanssa saadaan syntymään luottamussuhde ja että nuori sitoutuu hänelle tarjottuun tukeen. Yhteistyötä tehdään myös järjestöjen kanssa, jotta tuki varmistetaan ja sitä on saatavilla myös virka-ajan ulkopuolella. Hankkeessa keskeistä on pilottiprojektien seuranta ja tutkimuksellinen arviointi. Tavoitteena on löytää hyvä toimintamalli, jota voidaan jalkauttaa hankerahoituksen päätyttyä ja skaalata muihin kaupunkeihin ja kuntiin. (Ks. Sambou \& Piispa, 2019.)

Nuorten rikollisuutta ehkäisevää työtä tehdään monella rintamalla. Eri hallinnonaloilla rikoksilla oireileville nuorille on kehitetty erilaisia auttamisen muotoja, kuten poliisin moniammatillinen ennalta estävä toiminta (esim. Ankkuri), rikosten ja riitojen sovittelun erilaiset muodot, monien eri järjestöjen tekemä työ sekä osaltaan etsivä nuorisotyö. Varhaiskasvatuksessa ja kouluissa luodaan pohjaa sille, miten toimitaan toisten nuorten kanssa. Lastensuojelu tekee merkittävää työtä nuorten syrjäytymisen ehkäisyssä. Järjestöt tekevät tärkeää työtä rikoksen uhrin auttamisessa. Näin vähennetään rikoksista aiheutuvia haittoja ja uudelleen uhriksi joutumisen riskiä. Menetelmien kirjossa tärkeää on pitää mielessä, että useimmille nuorista riittää kevyt menettely eikä raskaalle toimenpidepatteristolle ole tarvetta kuin vaikeimmissa tapauksissa.

Palveluja kehitetään myös nuorille rikosten uhreille. Lapsi tai nuori on usein heikommassa asemassa kuin aikuinen, sillä hän ei välttämättä aina ymmärrä joutuneensa rikoksen uhriksi eikä tunne omia oikeuksiaan. Hän ei useinkaan tunnista tarvitsevansa apua eikä tiedä, mistä apua voisi saada. Auttavia toimia suunniteltaessa uhritutkimuksista ja muista tutkimuksista saatavat tiedot ovat ensiarvoisen tärkeitä.

Pyrkimyksenä on, että rikoksentorjunta sisällytetään kunnan strategiaan ja hyvinvointi- ja turvallisuustyöhön niin, että varmistetaan rikoksentorjuntatoimien toteutuminen paikallisella tasolla eri hallinnonalojen yhteistyönä (Turvallisesti yhdessä, 2016). Kunnallisessa turvallisuussuunnittelussa seurantatietojen hyödyntäminen on keskeistä. Tietoa hyvistä käytännöistä ja toimintamalleista pitää jakaa paikallistasolle, ja siihen tarvitaan resursseja.

Kolmannen sektorin toimijat pyritään ottamaan mukaan suunnitteluun ja toteutukseen, koska niillä on usein tietoa eri väestöryhmien, kuten etnisten vähemmistöjen, maahanmuuttajien, nuorten ja ikääntyneiden tilanteesta. Niin sanottu hiljainen tieto ei kantaudu viranomaisille. Järjestöjen vahvuutena ovat myös matalan kynnykset palvelut, joihin monien voi olla helpompi ottaa yhteyttä etenkin, jos viranomaisiin ei osata täysin luottaa.

Vaikka nuorisorikollisuutta vähennetään ja nuorten syrjäytymistä ehkäistään erilaisilla hankkeilla ja viranomaisten tukitoimilla, tietoa niiden muodoista, toiminnasta ja vaikuttavuudesta on saatavilla suhteellisen vähän. Ilman riittävää tieteellistä pohjaa palvelut eivät välttämättä toteudu odotetusti, ja ne voivat jopa lisätä uusintarikollisuutta. Vaikuttavuustutkimusten lisäämiselle onkin selvästi tilausta.

Martti Lehden (2017) systemaattisessa tutkimuskatsauksessa tarkasteltiin sekä kansainvälisiä että pohjoismaisia tutkimuksia rikoksentorjunnan kannattavuudesta. Kansainväliset tutkimukset olivat näyttötasoltaan vahvoja, ja niissä kannattavimmiksi todettiin korkean riskin lapsille ennen kouluikää tai viimeistään alakouluiässä suunnatut toimenpiteet sekä yksinkertaiset tekniset tilannetorjuntamenetelmät. Tilannetorjunta sisältää hyvin erilaisia menetelmiä, kuten kameravalvontaa ja poliisin kohdistettua valvontatoimintaa. Nämä keinot ovat kannattavia edullisuutensa vuoksi. Myös nuorten rikollisuuden ehkäisemisen kustannusvaikutuksia on arvi- 
oitu. Syrjäytymisen ehkäisyn ja ennaltaehkäisevän toiminnan merkityksestä on tehty laskelmia erilaisin kriteerein.

Tuoreen TEAS-tutkimushankkeen (Haikkola ym., 2019) kirjallisuuskatsauksen mukaan pelottelu ja valvonta eivät ole tehokkaita keinoja nuorten rikollisuuden torjumiseksi. Osalle nuorista riittää kevyt puuttuminen, kuten puhuttelu. Laajat ja pitkäkestoiset interventiot tulisi kohdistaa nuoriin, joiden riski uusia rikoksia on suuri. Perhettä osallistavien psykososiaalisten ja terapeuttisten menetelmien vaikuttavuudesta on positiivista tutkimusnäyttöä. Suomalaisten käytäntöjen tarkastelu osoittaa, että systematisoidut mallit keskittyvät varhaiseen puuttumiseen, kuten ensikertalaisten puhuttamiseen ja arviointiin. Sen sijaan rikosten uusijoiden ja vakavammin oireilevien kohderyhmää ei samalla tavoin ole otettu huomioon, eikä desistanssia tukevia menetelmiä ole kehitetty riittävästi. Rikosoikeuden ja lastensuojelun prosesseja ei aina soviteta yhteen nuoren edun mukaisesti, koska nuoren palvelukokonaisuudella ei ole selkeää vastuutahoa. Tutkimusta varten haastatellut nuoret kokivat, että tukipalveluja on niukasti. Vankempaa tukea tarvitseville nuorille tulisi systemaattisemmin kehittää pitkäkestoisia palveluita ja vahvistaa nuorisososiaalityötä. Eri toimialojen työtä tulisi koordinoida ja vastuunjakoa selkeyttää. Vaikuttavia ja kustannustehokkaita palveluita tulee etsiä suunnitelmallisen kokeilutoiminnan avulla, joissa kiinnitetään huomiota toimintamallien laadukkaaseen implementointiin. (Haikkola ym., 2019.)

\section{Lopuksi}

Nuorten rikokset ovat vakiintunut poliitikkojen huoli ja median kestoaihe. Kriminaalipolitiikan ja rikoksentorjunnan suunnittelussa tutkimuksellisen kokonaiskuvan saaminen nuorten rikollisuustilanteesta on ensiarvoisen tärkeää. Rikollisuuteen liittyvät kysymykset ovat muodostuneet yhä vahvemmin poliittisen keskustelun ainesosaksi ja ylilyöntien hillitsemiseksi tulisi olla käytettävissä ajantasaista tietoa nuorten rikollisuustilanteesta.

Säännöllisesti kerättävät kokonaisrikollisuustiedot ja muut indikaattorit ovat tässä ensiarvoisen tärkeitä. Samoin tarvitsemme tutkimustietoa rikoksentorjuntakeinojen vaikuttavuudesta. Näiden lisäksi on syytä kokeilla uusia keinoja, joiden vaikuttavuutta ei vielä tiedetä, mutta jota voidaan pyrkiä arvioimaan. On tärkeää myös kuulla nuorten omia kokemuksia ja näkemyksiä rikoksentorjunnasta. Nuorilta itseltään kerättyä tietoa tulee hyödyntää nuoria koskevassa päätöksenteossa.

Tutkimustiedon saatavuutta ja hyödynnettävyyttä on myös parannettava valmistelussa ja päätöksenteossa. Valmistelijoiden tutkimusosaamista on vahvistettava ja tähän on tarjottava koulutusta. Tutkimusrahoitusta ja tutkimuksen tilaajaosaamista tulee vahvistaa. Tietoon perustuva päätöksenteko edellyttää hyvää tietopohjaa, analyysitaitoja ja poliittista tukea onnistuakseen. Yhteistyö yliopistojen ja muun tutkimusmaailman kanssa on oleellista. Tavoitteisiin pääsemiseksi täytyy ponnistella aktiivisesti.

\section{KIRJALLISUUS}

Berg P. \& Myllyniemi, S. (toim.) (2021). Palvelu pelaa! Nuorisobarometri 2020. Valtion nuorisoneuvosto, Nuorisotutkimusseura/Nuorisotutkimusverkosto, Opetus- ja kulttuuriministeriö.

Danielsson, P. (toim.) (2020). Rikollisuustilanne 2019. Rikollisuuskehitys tilastojen ja tutkimusten valossa (Katsauksia 42/2020). Helsinki: Helsingin yliopisto, Kriminologian ja oikeuspolitiikan instituutti. 
Fagerlund, M., Peltola, M., Kääriäinen, J., Ellonen, N., \& Sariola, H. (2014). Lasten ja nuorten väkivaltakokemukset 2013. Lapsiuhritutkimuksen tuloksia (Poliisiammattikorkeakoulun raportteja 110). Tampere.

Haapasalo-Pesu, K-M., Lahti, I., Kronström, K., Ollikainen, S., Raevuori, A., Serimaa, K., Tuominen, T., \& Laukkanen, E. (2020). Nuoren tulisi saada tarvitessaan hyvää nuorisopsykiatrista hoitoa. Lääkärilehti, 48/2020.

Haikkola, L., Hästbacka, N., \& Pekkarinen, E. (toim.) (2019). Kuka vastaa nuorten rikoksiin. Ammattilaisten, nuorten ja kustannusten näkökulmia palveluihin (Valtioneuvoston selvitys- ja tutkimustoiminnan julkaisusarja 2019:3). Helsinki.

Honkatukia, P. \& Kivivuori, J. (toim.) (2006). Nuorisorikollisuus. Määrä, syyt ja kontrolli (Oikeuspoliittisen tutkimuslaitoksen julkaisuja 221 \& Nuorisotutkimusverkosto/Nuorisotutkimusseura julkaisuja 66). Helsinki.

Kaakinen, M. \& Näsi, M. (2021). Nuorten rikoskäyttäytyminen ja uhrikokemukset 2020 (Katsauksia 47/2021). Helsinki: Helsingin yliopisto, Kriminologian ja oikeuspolitiikan instituutti.

Lasten ja nuorten hyvinvointi - Kouluterveyskysely 2019 (Tilastoraportti 33/2019, 17.9.2019). THL.

Naisiin kohdistuvan väkivallan torjuntaohjelma vuosille 2020-2023 (Oikeusministeriön julkaisuja. Mietintöjä ja lausuntoja 15/2020). Helsinki.

Niemi, H. (toim.) (2018). Rikollisuustilanne 2017. Rikollisuuskehitys tilastojen ja tutkimusten valossa (Katsauksia 29/2018). Helsinki: Helsingin yliopisto, Kriminologian ja oikeuspolitiikan instituutti.

Näsi, M. (2016). Nuorten rikoskäyttäytyminen ja uhrikokemukset 2016 (Katsauksia 18/2016). Helsinki: Helsingin yliopisto, Kriminologian ja oikeuspolitiikan instituutti.
Näsi, M., Virtanen, M., \& Tanskanen, M. (2017). Oppilaitosten turvallisuustutkimus 2016 (Katsauksia 20/2017). Helsinki: Helsingin yliopisto, Kriminologian ja oikeuspolitiikan instituutti.

Pawson, R. \& Tilley, N. (1997). Realistic Evaluation. Sage.

Ristikari, T., Törmäkangas, L., Lappi, A., Haapakorva, P., Kiilakoski, T., Merikukka, M., Hautakoski, A., Pekkarinen, E., \& Gissler, M. (2016). Suomi nuorten kasvuympäristönä. 25 ikävuoden seuranta vuonna 1987 Suomessa syntyneistä (Raportti 9/2016). Terveyden ja hyvinvoinnin laitos (THL) ja Nuorisotutkimusverkosto.

Ristikari, T., Keski-Säntti, M., Sutela, E., Haapakorva, P., Kiilakoski, T., Pekkarinen, E., Kääriälä, A., Aaltonen, A., Huotari, T., Merikukka, M., Salo, J., Juutinen, A., Pesonen-Smith, A., \& Gissler, M. (2018). Suomi lasten kasvuympäristönä. Kahdeksantoista vuoden seuranta vuonna 1997 syntyneistä (Raportti 7/2018 \& Nuorisotutkimusseuran julkaisuja 210/2018). Terveyden ja hyvinvoinnin laitos (THL) \& Nuorisotutkimusverkosto/Nuorisotutkimusseura.

Sambou, S. \& Piispa, M. (2019). Toimintamalli rikoksilla oireileville nuorille: Kehittämistyöryhmän ehdotus (Oikeusministeriön julkaisuja, Selvityksiä ja ohjeita 26/2019). Helsinki.

Sitra (2019). Tiedonkäytön tulevaisuus yhteiskunnallisessa päätöksenteossa. Työpaperi 20.9.2019.

Turvallisesti yhdessä (2016). Kansallinen rikoksentorjuntaohjelma (Oikeusministeriö, Selvityksiä ja ohjeita 30/2016). Helsinki.

Vauhkonen, T., Kallio, J., \& Erola, J. (2017). Sosiaalisen huono-osaisuuden ylisukupolvisuus Suomessa. Yhteiskuntapolitiikka, 82(5), 501-512. 